\author{
Alicja Rafalska-Lasocha \\ ORCID 0000-0001-7642-8845 \\ Wydział Chemii UJ, Zakład Chemii Nieorganicznej (Kraków, Polska) \\ rafalska@,chemia.uj.edu.pl
}

\title{
O Marii Skłodowskiej-Curie w 150. rocznicę urodzin
}

\begin{abstract}
Abstrakt
Artykuł poświęcony jest obchodom 150. rocznicy urodzin dwukrotnej laureatki Nagrody Nobla, odkrywczyni polonu i radu, pierwszej kobiecie profesor Sorbony, która w rankingu zorganizowanym przez periodyk New Scientist uznana została za najwybitniejszą i najbardziej inspirującą uczoną wszechczasów.

W młodości Marii wiele uniwersytetów (w tym także polskie) było zamkniętych dla kobiet, więc Skłodowska studiowała na Sorbonie w Paryżu. Kiedy po studiach nie zaproponowano jej asystentury na Uniwersytecie Jagiellońskim w Krakowie, wróciła do Paryża, poślubiła Piotra Curie i rozpoczęła pracę naukową w jego skromnym laboratorium.

Osiagnnięcia naukowe Marii Skłodowskiej-Curie były przełomem w historii nauk ścisłych i podstawą do zastosowania
\end{abstract}

\begin{tabular}{|c|c|c|c|c|c|}
\hline \multicolumn{2}{|c|}{$\begin{array}{l}\text { INFORMACJA } \\
\text { O PUBLIKACJI }\end{array}$} & $\begin{array}{l}\text { Ptudia } \\
\text { Sistoriae } \\
\text { cientiarum }\end{array}$ & $\begin{array}{r}\text { e-ISSN 2543-702X } \\
\text { ISSN 2451-3202 }\end{array}$ & 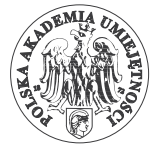 & $\begin{array}{l}\text { } \\
\text { BRYLANTOWY MODEL } \\
\text { OTWARTEGO DOSTĘPU }\end{array}$ \\
\hline \multicolumn{6}{|c|}{$\begin{array}{l}\text { CYTOWANIE } \\
\text { Rafalska-Łasocha, Alicja 2018: O Marii Skłodowskiej-Curie w 150. rocznicę urodzin. Studia Historiae } \\
\text { Scientiarum 17, ss. 501-521. } \\
\text { Dostęp online: } \underline{\text { https://doi.org/10.4467/2543702XSHS.18.018.9338. }}\end{array}$} \\
\hline \multicolumn{3}{|c|}{$\begin{array}{l}\text { OTRZYMANO: } 19.12 .2017 \\
\text { ZAAKCEPTOWANO: } 21.09 .2018 \\
\text { OPUBLIKOWANO ONLINE: } 12.12 .2018\end{array}$} & $\begin{array}{l}\text { POLITYKA } \\
\text { ARCHIWIZOWANIA } \\
\text { Green SHERPA / } \\
\text { ROMEO Colour }\end{array}$ & 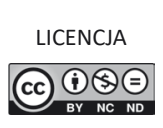 & Crossref \\
\hline www & http:// & ejournals.eu/ & ex.php/SHS/; http:// & krakow.pl/Stu & -Historiae-Scientiarum/ \\
\hline
\end{tabular}


nowych metod w terapiach onkologicznych. Dla obecnych naukowców jest ponadczasowym źródłem inspiracji i jest podziwiana nie tylko za osiagnięcia naukowe, ale także za odwagę w przełamywaniu barier i pomoc w redefiniowaniu roli kobiet w społeczeństwie i nauce.

W dniu 7 listopada 2017 r. świętowaliśmy 150. rocznicę urodzin Marii Skłodowskiej-Curie. W Polsce i za granica przez cały 2017 rok zorganizowano wiele wydarzeń, upamiętniających jej życie i osiagnięcia. Niektóre z nich, a także pewne aspekty życia i pracy Skłodowskiej-Curie, zostały opisane w niniejszym artykule.

Słowa kluczowe: Maria Skłodowska-Curie, promieniotwórczość, odkrycie polonu i radu, jubileusz. 150. rocznicy urodzin Marii Sktodowskiej-Curie

\title{
About Marie Skłodowska-Curie on the occasion of her 150th anniversary of the birth
}

\begin{abstract}
The article regards the celebrations of the 150th anniversary of the birth of Marie Sklodowska-Curie - a discoverer of polonium and radium, twice decorated with a Noble Prize, the first woman professor of the Sorbonne, who in the ranking organized by the periodical New Scientist was considered the most outstanding and inspiring scientist of all time.

In her youth, many universities (among them also Polish) were closed to women, so Marie Skłodowska studied at the Sorbonne in Paris. When, after her studies, she was not accepted as an assistant at the Jagiellonian University in Kraków (Poland), Marie Skłodowska came back to Paris, married Pierre Curie and started her scientific work in his humble lab.

The scientific achievements of Maria Skłodowska-Curie were a breakthrough in the history of exact sciences and the basis for the application of new methods in oncological therapies.

For modern scientists she is a timeless source of inspiration and is admired not only for her scientific achievements but also for her courage in breaking barriers and helping to redefine the role of women in society and science.
\end{abstract}


On November 7, 2017, we celebrated the 150th anniversary of Marie Skłodowska-Curie's birth. In Poland and abroad many events were organized during the whole year of 2017 to commemorate her life and achievements. Some of them, as well as some aspects of Skłodowska-Curie's life and work are described in this paper.

Keywords: Marie Sktodowska-Curie, radioactivity, discovery of polonium and radium, 150th anniversary of Marie Sktodowska-Curie's birth

\section{Wstęp}

Maria Skłodowska urodziła się w czasie, gdy Polska nie istniała na mapie świata, a uczeni sądzili, że świat zbudowany jest z atomów, atom natomiast jest jednorodna i niepodzielną cząstką materii. Jej naukowe osiagnięcia były początkiem zmiany podstawowych poglądów na budowę materii i przełomem w fizyce na początku XX wieku.

Maria była najmłodszym dzieckiem z pięciorga rodzeństwa. Wychowywała się w nauczycielskiej rodzinie, w której panował szacunek dla zdobywania wiedzy i w której kultywowano patriotyczne tradycje. Biografia Marii jest powszechnie znana dzięki licznym książkom i publikacjom opisującym jej niełatwe życie ${ }^{13}$. W Polsce nie mogła studiować, wyjechała więc w 1891 r. do Paryża i rozpoczęła tam studia na Sorbonie. Po uzyskaniu licencjatu z fizyki i matematyki chciała wrócić w 1894 r. do kraju i pracować na uniwersytecie w Krakowie, lecz kobiety jeszcze wówczas nie mogły nawet studiować w Uniwersytecie Jagiellońskim. Maria Skłodowska nie uzyskała więc posady w laboratorium fizycznym prof. Augusta Witkowskiego ${ }^{14}$. Wróciła do Paryża, gdzie wspólnie z mężem Piotrem Curie podjęła pracę nad promieniowaniem uranu i w 1898 r. odkryła nowe pierwiastki polon i rad. Wyniki tych badań uczeni ogłosili w kilku publikacjach ${ }^{15}$. W 1903 r. Maria Skłodowska-Curie obroniła pracę doktorską ${ }^{16}$. W tym samym roku wspólnie z Piotrem Curie

13 Publikacji o życiu uczonej jest bardzo wiele, wymieńmy więc tylko te najważniejsze w opinii autorki: Skłodowska-Curie 1959; E. Curie 1997; Joliot-Curie 1998; Brian 2006, Kabzińska i in. 1994; Cotton 1965.

${ }^{14}$ Rafalska-Łasocha 2015.

${ }^{15}$ P. Curie, Mme P. Curie 1898; P. Curie, Mme P. Curie, Bémont 1898; P. Curie, Mme P. Curie 1900.

${ }^{16}$ Mme Sklodowska-Curie 1903. 
i Henri Becquerelem otrzymała Nagrodę Nobla za badania odkrytego przez Becquerela promieniowania. Po śmierci męża, który zginął w tragicznym wypadku w 1906 r., objęła po nim katedrę fizyki na Sorbonie, a w 1908 r. została pierwszą kobieta profesorem tej uczelni. Przez lata borykała się samotnie ze zorganizowaniem laboratorium i badaniami nad wydzieleniem i właściwościami nowo odkrytych pierwiastków promieniotwórczych. Publikując wszystkie wyniki i nie zastrzegając swych rezultatów patentowymi obwarowaniami, znacznie przyczyniła się do szybkiego rozwoju przemysłu radowego i zastosowania substancji promieniotwórczych do celów medycznych. Po śmierci uczonej, w trakcie uroczystości na jej cześć Albert Einstein powiedział:

Kiedy życie tak niezwykłej osobowości jak Pani Curie dobiegło końca, powinniśmy pamiętać o jego znaczeniu dla całej ludzkości. Wartości etyczne reprezentowane przez czołowe osobistości w każdym pokoleniu mają bowiem głębsze znaczenie dla tego pokolenia i całego biegu historii niż tylko ich intelektualne osiagnięcia (Ham 2002-2003).

Od czasu aktywności naukowej Marii Skłodowskiej-Curie minęło ponad sto lat. Kolejne rocznice związane z jej odkryciami i jej osobą są wciąż okazją do przypomnienia osiagnięć uczonej i prezentowanych przez nią wartości. Taką okazją była również 150 . rocznica urodzin, która w Polsce i we Francji obchodzona była szczególnie uroczyście. Nie sposób opisać wszystkich wydarzeń związanych z tą okragła rocznica, warto jednak wspomnieć chociaż niektóre z nich, zorganizowane w wielkich i całkiem małych miastach i wioskach. Wydarzeń, które miały ogromny, światowy zasięg i takich, które skierowane były do lokalnej społeczności szkół lub innych instytucji użyteczności publicznej.

\section{Uroczystości rocznicowe we Francji}

Maria Skłodowska urodziła się w Warszawie, ale we Francji spędziła swe zawodowe życie i tam też miały miejsce najważniejsze wydarzenia w jej pracy naukowej. Chociaż przez cały rok 2017 zorganizowano wiele różnorodnych wydarzeń poświęconych uczonej, najważniejszy był jednak dzień jej urodzin -7 listopada. 


\section{Panteon}

W paryskim Panteonie, gdzie przy wejściu wyryto słowa: „Wielkim Ludziom - Wdzięræna Ojçyzna” i gdzie spoczywają prochy Marii i Piotra Curie, otwarto uroczyście wystawę „Maria Curie - kobieta w Panteonie”. Zorganizowały ją Instytut Curie, Muzeum Curie i Centrum Zabytków Narodowych w Paryżu. Wśród prezentowanych eksponatów można było zobaczyć dokumenty, fotografie, listy, przyrządy naukowe i przedmioty osobiste, przyblizające zwiedzającym obraz Marii SkłodowskiejCurie jako naukowca, ale także jako kobiety i matki. Wystawa podzielona była na pięć części, obrazujących kolejne etapy w życiu uczonej. Opisy eksponatów i plansze wystawowe prezentowane były w trzech językach: francuskim, angielskim i polskim.

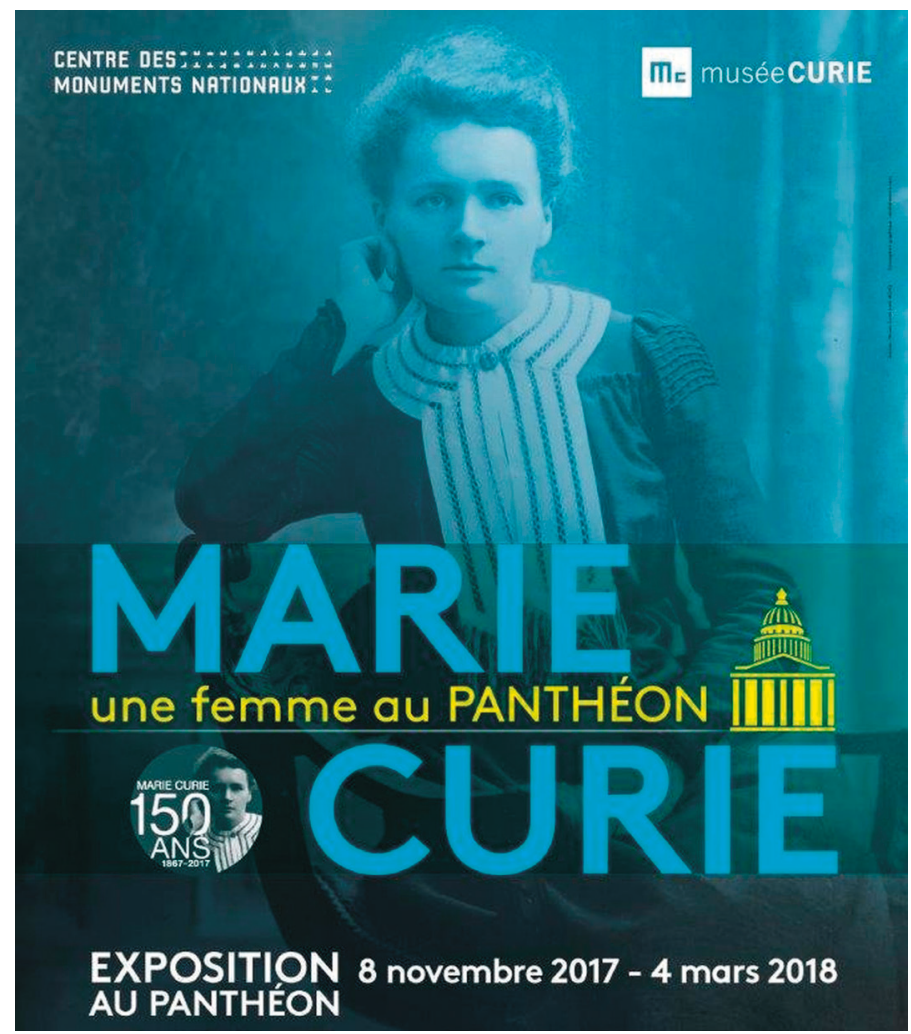

Ryc. 1. Plakat i zaproszenie na otwarcie wystawy w Panteonie (ze zbiorów Alicji Rafalskiej-Łasochy). 


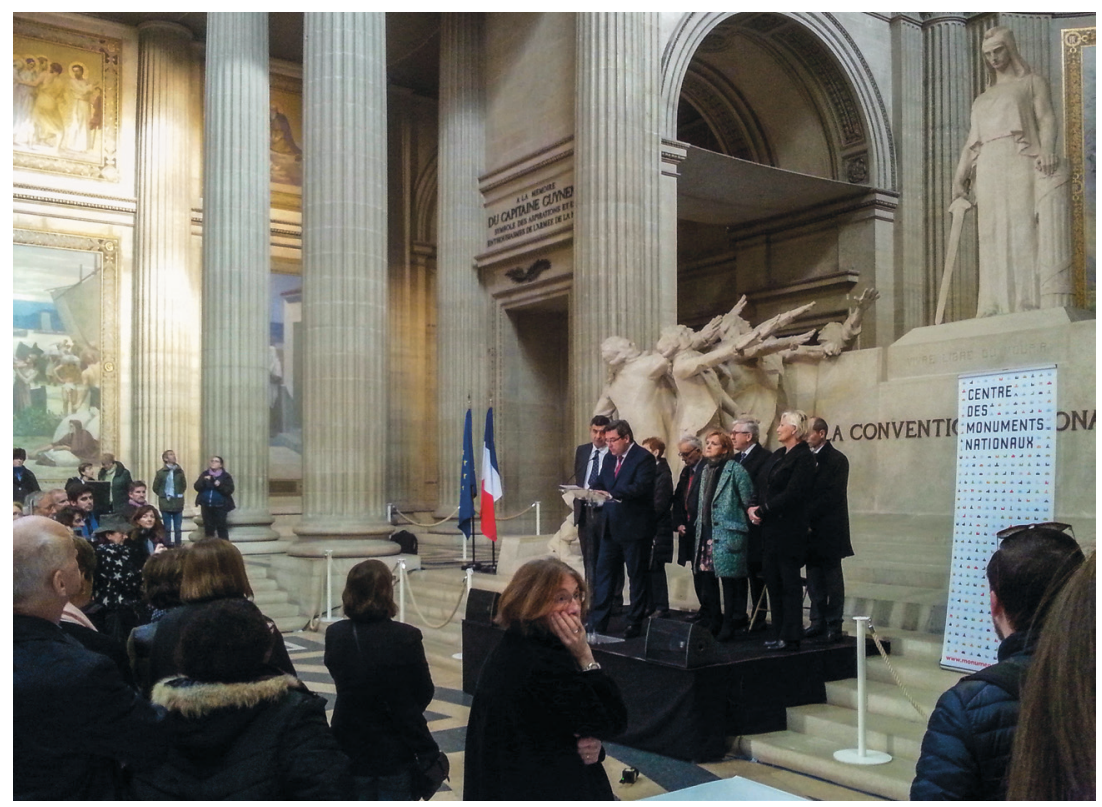

Ryc. 2. Ceremonia otwarcia wystawy „Maria Curie - kobieta w Panteonie” - przemowa ambasadora RP we Francji Tomasza Młynarskiego (fot. Alicja Rafalska-Łasocha).

W otwarciu wystawy uczestniczył ambasador RP we Francji Tomasz Młynarski, wnuki Marii i Piotra Curie - prof. Hélène Langevin-Joliot i prof. Pierre Joliot, przedstawiciele organizatorów, politycy i wielu gości zaproszonych z całego świata. Ambasador Młynarski podkreślił w swoim przemówieniu, że Maria Skłodowska-Curie jest symbolem walki o przesuwanie granic nauki, ale również granic obowiązujących norm społecznych. Powiedział również:

należy pamiętać, że Maria Skłodowska-Curie, Polka, która przyjechała do Francji, żeby podjąć studia, nigdy nie zapomniała o swojej Ojczyźnie, znajdującej się wówczas pod zaborami. Zabiegała o uznanie i rozwój polskiej nauki, a jej największym marzeniem - jak sama mówiła - było utworzenie Instytutu Radowego w Warszawie.

Wystawa w Panteonie była eksponowana do 4 marca 2018 r. Zwiedziło ją zapewne liczne grono Francuzów i zagranicznych turystów tłumnie odwiedzających Paryż. W otwarciu wystawy uczestniczyli również goście 


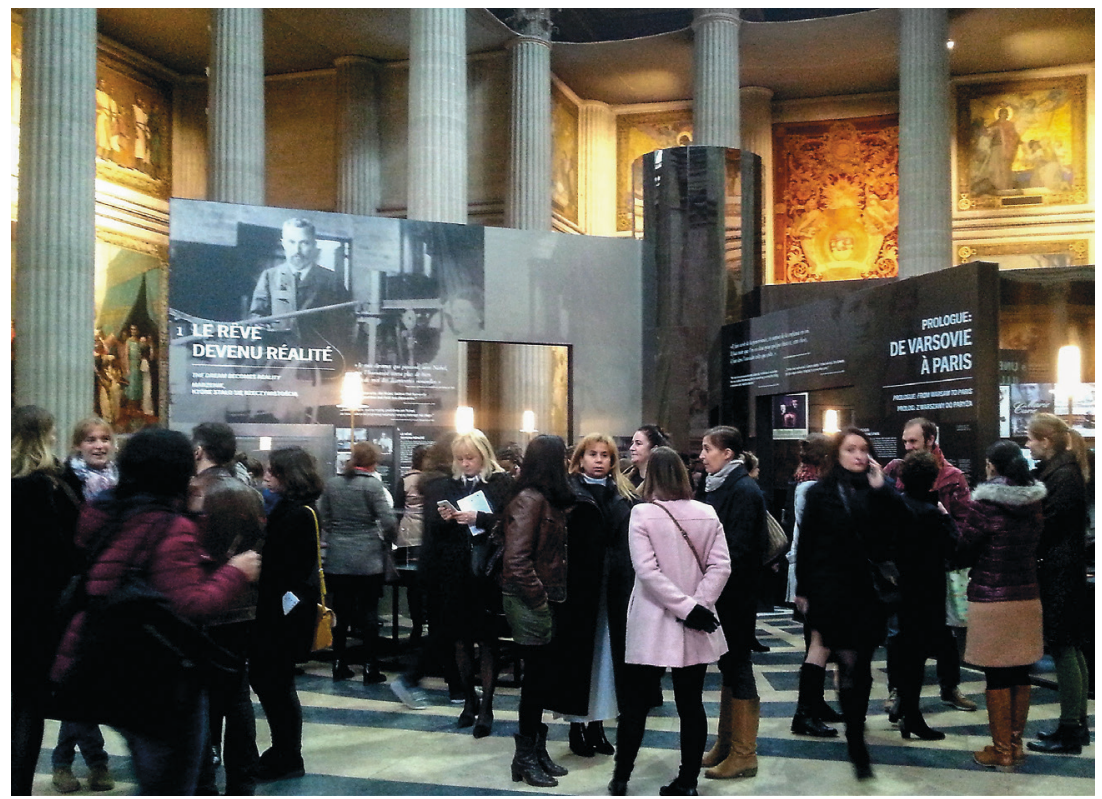

Ryc. 3. Fragment wystawy „Maria Curie - kobieta w Panteonie” (fot. Alicja Rafalska-Zasocha).

z Polski, a pośród nich prorektor ds. studenckich Uniwersytetu Marii Curie-Skłodowskiej w Lublinie prof. dr hab. Urszula Bobryk, prof. dr hab. Krzysztof Pomorski z Katedry Fizyki Teoretycznej UMCS, pani Małgorzata Ewa Rosen - kustosz Muzeum Marii Skłodowskiej-Curie Polskiego Towarzystwa Chemicznego w Warszawie, prof. Wiesław Łasocha z Wydziału Chemii Uniwersytetu Jagiellońskiego, jak też autorka niniejszej publikacji. Licznie odwiedzana była również krypta w podziemiach Panteonu, gdzie znajdują się sarkofagi z prochami Marii i Piotra Curie.

\section{Instytut Curie}

Popołudniową sesję poświęconąuczonej, która miała miejsce w Instytucie Curie przy ul. Lhomond 12, rozpoczał prezydent Instytutu prof. Thierry Philip okolicznościowym przemówieniem. Następnie głos zabrały przedstawicielki rządu Francji pani Frédérique Vidal - minister szkolnictwa wyższego, badań naukowych i innowacji oraz pani Agnès Buzyn - minister solidarności i zdrowia, wspominając zasługi naszej rodaczki dla nauki i społeczeństwa we Francji i na świecie. Następnie zaprezentowano film, 


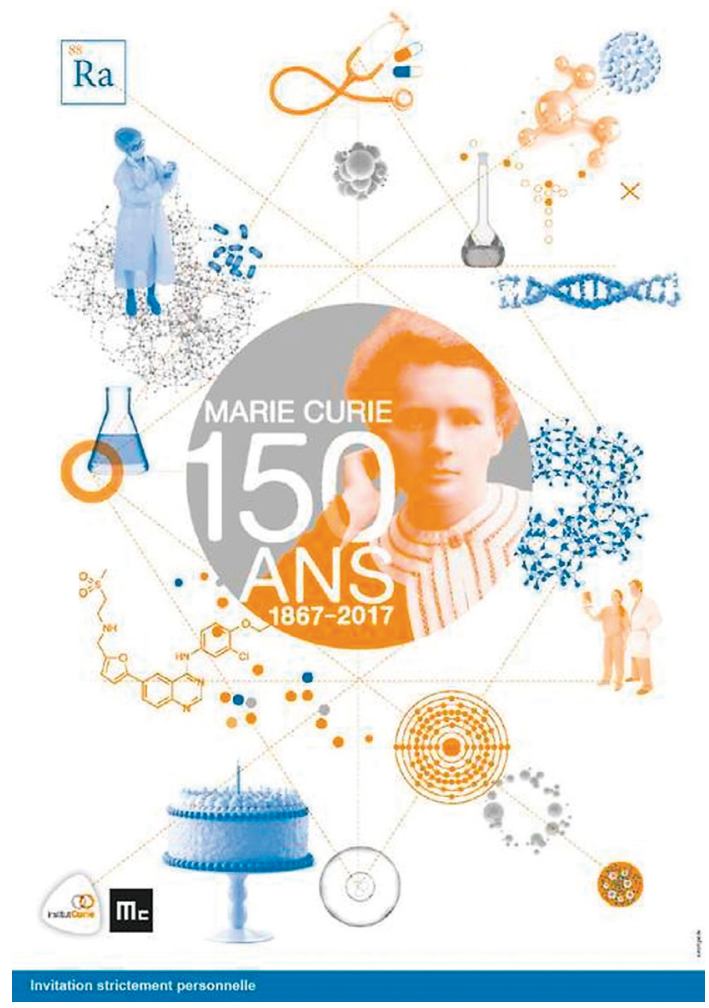

Ryc. 4. Zaproszenie na uroczystą sesję poświęconą Marii Curie w Instytucie Curie w Paryżu (ze zbiorów Alicji Rafalskiej-Łasochy).

w którym pokazano znaczenie postaci uczonej dla międzynarodowej społeczności poprzez indywidualne wypowiedzi osób w różnym wieku, o różnym statusie społecznym i różnej narodowości ${ }^{17}$.

W trakcie sesji zabrała również głos Andrée Dutreix, współpracowniczka Ireny Joliot, pierwsza uczona specjalizująca się w fizyce medycznej we Francji, oraz wnuki Marii, szczególnie podkreślając znaczenie odkryć uczonej i jej zasługi dla medycyny. Wspominano zarówno jej udział w organizacji służby radiologicznej w czasie I wojny światowej, jak też późniejsze zaangażowanie w prace nad wykorzystaniem promieniowania do walki z chorobami nowotworowymi.

${ }^{17}$ Institut Curie 2017. 


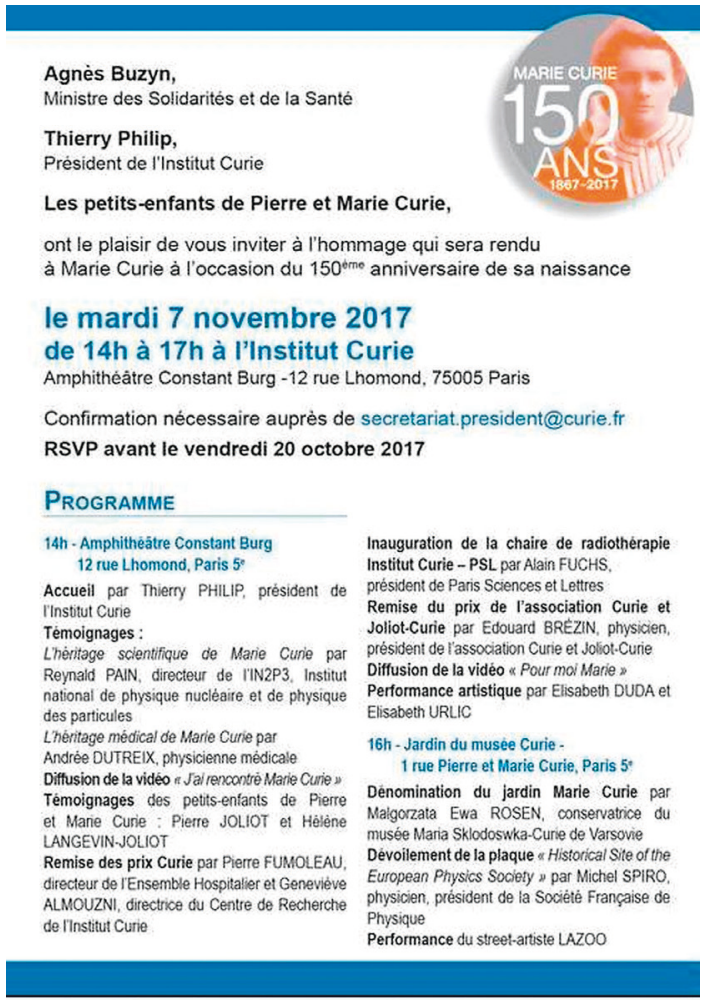

Ryc. 5. Program uroczystej sesji poświęconej Marii Curie w Instytucie Curie w Paryżu (ze zbiorów Alicji Rafalskiej-Łasochy).

Wielokrotnie w trakcie uroczystości rocznicowych podkreślano osobiste zaangażowanie uczonej w wykonywanie badań rentgenowskich rannych żołnierzy na wielu frontach francuskich działań wojennych. Dzień urodzin Marii jest bliski dacie zakończenia Wielkiej Wojny (11 listopada), we Francji dzień ten świętowany jest w szczególny sposób. Dobitnie podkreślano więc też udział Marii w szkoleniu lekarzy wojskowych i uświadamianiu im użyteczności promieni Roentgena w lokalizacji odłamków w ciałach rannych żołnierzy. Pomimo że od okrycia promieni X (1895 r.) do czasów I wojny światowej minęły dwie dekady, wiedza na temat ich zastosowania do celów medycznych nie była powszechna. Zaangażowanie Skłodowskiej-Curie w tej dziedzinie było bardzo znaczace. Uczona przeprowadziła wiele szkoleń na temat wykorzystania promieni X w medycynie, a po wojnie napisała książkę pt. Radiologia 


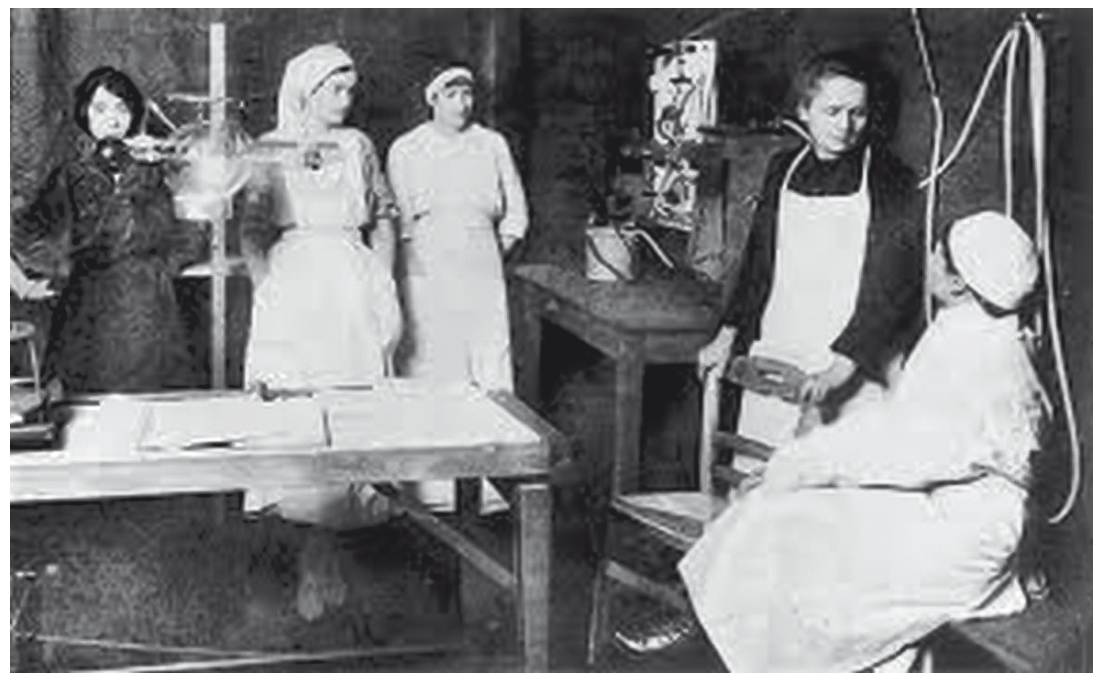

Ryc. 6. Maria Skłodowska-Curie w czasie szkolenia personelu medycznego o zastosowaniu promieni X w medycynie (licencja PD, Wikimedia Commons).

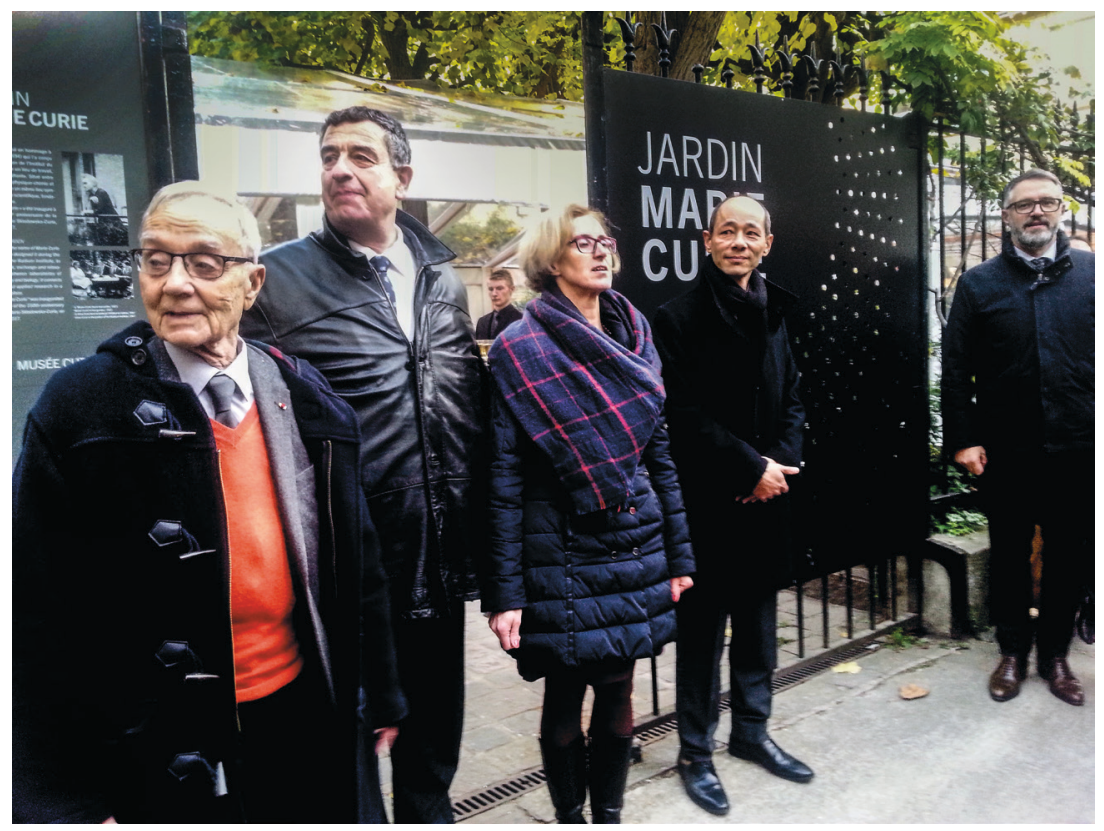

Ryc. 7. Uroczyste otwarcie ogrodu Marii Curie. Stoją od lewej: Prof. Pierre Joliot, Prof. Thierry Philip, pani Małgorzata Rosen i pan Renaud Huynh (fot. Alicja Rafalska-Łasocha). 
i wojna, by upowszechnić znaczenie zastosowania nowych technik diagnostycznych do celów medycznych ${ }^{18}$.

Na zakończenie uroczystej sesji wręczono nagrody Fundacji Curie młodym badaczom, po czym aktorka Elżbieta Duda i wiolonczelistka Elisabeth Urlic zaprezentowały montaż słowno-muzyczny nawiązujacy do biografii Marii Skłodowskiej-Curie.

\section{Muzeum Curie}

Po zakończeniu uroczystej sesji jej uczestnicy udali się do ogrodu Muzeum Curie przy ul. Pierre et Marie Curie 1, gdzie pani Małgorzata Ewa Rosen, kustosz Muzeum Marii Skłodowskiej-Curie Polskiego Towarzystwa Chemicznego w Warszawie, wspólnie z prezydentem Instytutu Curie prof. Thierry Philipem i dyrektorem Muzeum Curie Renaud Huynhem, w obecności wnuków Marii i licznie zgromadzonych gości nadali ogrodowi imię Marii Curie. Ogród ten powstał, zanim jeszcze zbudowano laboratorium Curie. Uczona sama sadziła w nim drzewa, a potem ogród był miejscem krótkiego odpoczynku, w trakcie i po pracy, dla wszystkich pracowników laboratoriów Instytutu Radowego.

Zainteresowanie uczonej przyroda jest mało znanym elementem jej życia i ostatnio zostało ono przypomniane w ramach obchodów rocznicowych ${ }^{19}$. W ogrodzie przy Muzeum Curie prezentowana była te $\dot{z}$ wystawa „Maria Skłodowska-Curie i świat” przygotowana przez muzeum Marii Skłodowskiej-Curie w Warszawie i Muzeum Curie w Paryżu. Paryskie muzeum jest również organizatorem wielu innych wydarzeń związanych z rocznicą urodzin Marii. Są wśród nich wykłady, spotkania $\mathrm{i}$ inne imprezy przypominające sylwetkę i osiagnięcia uczonejej ${ }^{20}$.

\section{Ambasada Polska w Paryżu}

Oprócz udziału pracowników ambasady w otwarciu wystawy w Panteonie, w dniu 7 listopada 2017 r. w budynku ambasady miało miejsce spotkanie z autorkami książek o Marii Skłodowskiej-Curie paniami Marie-Noëlle Himbert i Natachą Henry. Zebranych, wśród których byli

${ }^{18}$ M. Curie 1921

${ }^{19}$ Rafalska 2017. Wystawa „Maria Skłodowska-Curie i kwiaty”, zorganizowana przez Wydział Chemii UJ, eksponowana była w wielu ogrodach botanicznych w Polsce - zob. relacje z wystawy: Wydział Chemii UJ 2017.

${ }^{20}$ Muzeum Curie w Paryżu 2017. 
francuscy deputowani i przedstawiciele Grupy Przyjaźni Francja-Polska w Zgromadzeniu Narodowym, przywitał ambasador Tomasz Młynarski, który powiedział, że obok osiagnięć naukowych, Maria Skłodowska-Curie prezentowała wartości i idee niejednokrotnie wykraczające poza czasy, w których żyła, a także stanowiła - i stanowi nadal - swoisty pomost pomiędzy Polską a Francją. W trakcie spotkania mówiono o szczególnej relacji Marii z siostrą Bronisławą Dłuska, wykształcona również na Sorbonie, a pracującą w Polsce lekarką, która zrobiła bardzo wiele dla zorganizowania Instytutu Radowego w Warszawie. Podkreślono też szczególne zaangażowanie Marii w wykorzystanie promieniowania rentgenowskiego dla ratowania życia rannych żołnierzy. W 1915 r. w liście do jednego z kolegów fizyków Maria pisała:

Nie mogąc służyć nieszczęsnej mojej ojczyźnie skapanej we krwi po przeszło stu latach cierpień, postanowiłam oddać wszystkie siły mojej ojczyźnie przybranej ${ }^{21}$.

Zorganizowała przenośne, mieszczące się w podarowanych jej autach, stacje radiologiczne nazywane Petit Curie, jako jedna z pierwszych kobiet we Francji uzyskała prawo jazdy i jeździła po frontach działań wojennych, wykonując prześwietlenia rannych żołnierzy.

\section{Uroczystości rocznicowe w Polsce}

Imię Marii Skłodowskiej-Curie nosi w Polsce wiele ulic, szkól, szpitali $\mathrm{i}$ innych miejsc, instytucji i organizacji. Uroczystości rocznicowe rozpoczęły się już na początku 2017 r. na terenie całego kraju. Ponieważ, jak wspomniano wyżej, trudno byłoby wymienić je wszystkie, ograniczmy się do kilku przykładów.

\section{Polskie Towarzystwo Chemiczne i Muzeum Marii Skłodowskiej-Curie w Warszawie}

Warszawa, miasto rodzinne Marii, zawsze była bliska jej sercu. Tam powstał bliźniaczy do paryskiego Instytut Radowy - wielkie marzenie uczonej. Kiedy po raz ostatni Maria odwiedziła Warszawę, biorąc udział w otwarciu Instytutu, w liście do córki Ewy pisała:

${ }^{21}$ E. Curie 1997, s. 306. 
Poszłam wczoraj na samotny spacer w stronę Wisły. Rzeka leniwie toczy w szerokim łożysku swe wody, które z bliska wydają się mętne, lecz w dali błękitnieją odblaskami nieba. Urocze ławice piasku, rzucone tu i ówdzie, złocą się w promieniach słońca kapryśnymi skrętami kierując bieg fal. Wzdłuż brzegu tych mielizn olśniewająco jasne pasy znacza granicę głębi. Czuję nieodpartą potrzebę błądzenia po owych plażach, świetlistych, przecudnych. [...] Jest jedna piosenka krakowska, która mówi, że czar tych polskich wód jest tak wielki, iż kto je raz pokochał, nie zapomni ich do grobu. Co do mnie te słowa są całkiem prawdziwe. Ta rzeka ma dla mnie powab, którego istoty nawet pojać nie potrafię (E. Curie 1997).

W Warszawie ma swoją siedzibę Polskie Towarzystwo Chemiczne, a w kamienicy, w której przyszła na świat, działa Muzeum Marii Skłodowskiej-Curie. Pod patronatem tych instytucji odbywały się przez cały 2017 rok różne imprezy przypominające sylwetkę i odkrycia uczonej ${ }^{22}$. Pracownicy muzeum i władze PTCh aktywnie współpracowali z wieloma instytucjami w kraju i za granica w organizacji różnorakich wydarzeń związanych z rolą Marii Skłodowskiej-Curie w rozwoju nauki o promieniotwórczości. Kulminacyjnym punktem obchodów była konferencja „Medicina - Scientia - Cultura” (6-8.11.2017), z udziałem wnuków uczonej i gości z Paryża, zakończona uroczysta galą w dniu 9 listopada. Było to wydarzenie naukowo-kulturalne obejmujące wykłady ekspertów na temat związków uczonej z medycyna, naukami ścisłymi i społecznymi, wystawy i spektakle artystyczne ${ }^{23}$.

\section{Uniwersytet Marii Curie-Skłodowskiej w Lublinie}

150. urodziny patronki świętowano również uroczyście na uniwersytecie w Lublinie. Liczne imprezy dla studentów, uczniów i szerokiej publiczności trwały przez cały rok $2017^{24}$. Były spotkania z twórcami pokazanego na początku 2017 r. na ekranach polskich kin filmu o Noblistce,

${ }^{22}$ Muzeum Marii Skłodowskiej-Curie w Warszawie 2017.

${ }^{23}$ Centrum Dydaktyczne, Warszawski Uniwersytet Medyczny 2017.

${ }^{24}$ Zob. program obchodów: Uniwersytet Marii Curie-Skłodowskiej w Lublinie $2017 \mathrm{a}$. 
wystawy, wykłady i konkursy. Najmłodsi mogli zapoznać się z sylwetką uczonej w ramach Uniwersytetu Dzieci, a w październiku ukazał się specjalny numer Wiadomości Uniwersyteckich w całości poświęcony patronce uczelni ${ }^{25}$.

Po uroczystościach paryskich i warszawskich Lublin odwiedziła również delegacja z Paryża: wnuki Marii, dyrektor Muzeum Curie Renaud Huynh i dr Natalie Pigeard-Micault. Na ręce prorektora ds. nauki i współpracy międzynarodowej prof. Radosława Dobrowolskiego paryscy goście przekazali cenny dar związany z patronką UMCS: porozumienie pomiędzy Marią Curie, Claudiusem Regaud (Instytut Curie) oraz Emile'em Roux (Instytut Pasteura). Dokument zawiera oficjalne pozwolenie na wykorzystanie radu do badań ludzi.

\section{Inne wydarzenia jubileuszowe}

Oprócz wymienionych powyżej uroczystości związanych ze 150. rocznica urodzin Marii Skłodowskiej-Curie, w wielu miejscach Polski i świata również przypominano sylwetkę uczonej. Dla podkreślenia jej znaczenia w przestrzeni społecznej Poczta Polska wyemitowała kartkę pocztową i znaczek, honorując w ten sposób sylwetkę i osiagnnięcia Noblistki.

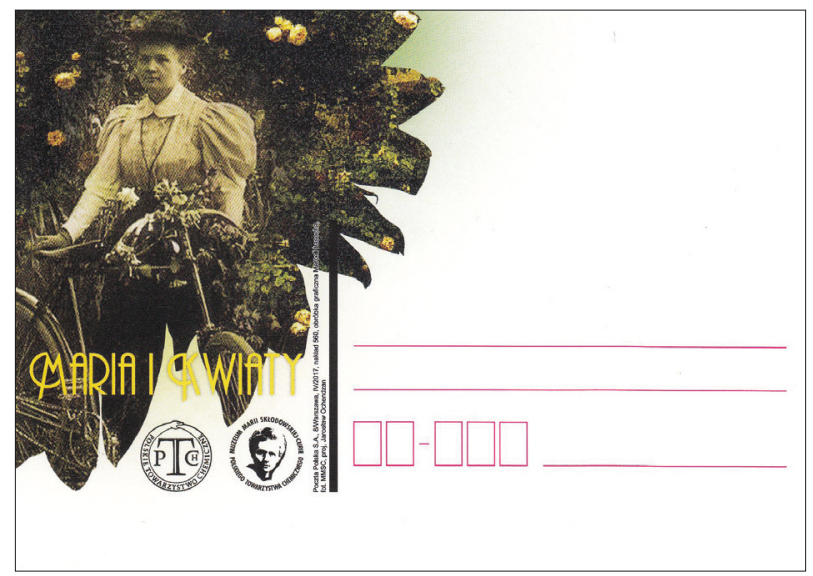

Ryc. 8. Karta pocztowa wyemitowana przez Pocztę Polską z okazji 150. rocznicy urodzin Marii Skłodowskiej-Curie (ze zbiorów Alicji Rafalskiej-Łasochy).

${ }^{25}$ Uniwersytet Marii Curie-Skłodowskiej w Lublinie 2017c. 


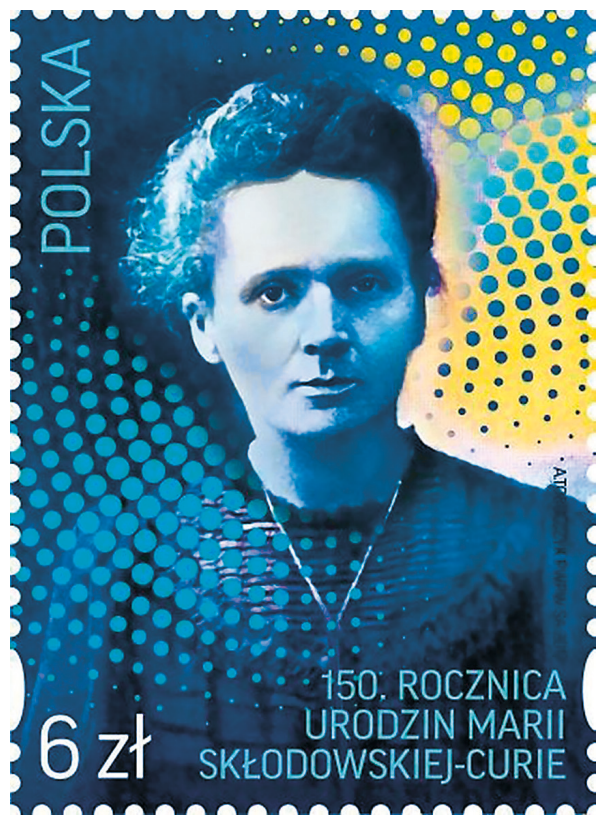

Ryc. 9. Znaczek pocztowy wyemitowany przez Pocztę Polska z okazji 150. rocznicy urodzin Marii Skłodowskiej-Curie (ze zbiorów Alicji Rafalskiej-Łasochy).

W obchody jubileuszu włączyły się również wydarzenia artystyczne. W początku roku miała miejsce premiera fabularnego filmu Maria Skłodowska-Curie nakręconego w koprodukcji francusko-niemiecko-polsko-belgijskiej, w reżyserii Marie Noëlle. Spektakl teatralny Promieniowanie, csyli rzecz o Marii Skłodowskiej-Curie według scenariusza i w reżyserii Kazimierza Brauna wystawiano w Teatrze Słowackiego w Krakowie, a Towarzystwo Marii Skłodowskiej-Curie - w Hołdzie i Instytut Teatralny im. Zbigniewa Raszewskiego zorganizowały również pokaz tej sztuki w Instytucie Teatralnym im. Zbigniewa Raszewskiego w Warszawie. Spektakl ten, grany przez Marię Nowotarską i Agatę Politowską - aktorki działające w Kanadzie w Salonie Poezji, Muzyki i Teatru, pokazano też jesienią 2017 r. w Muzeum Historii Medycyny i Farmacji Uniwersytetu Medycznego w Białymstoku, w The Maria SkłodowskaCurie Saturday School in Wimbledon and Puenty (Anglia) oraz innych miejscach w kraju i poza jego granicami.

Należy wspomnieć, że również w małych polskich szkołach rocznica urodzin Noblistki nie przeszła bez echa. Można by w tym miejscu 
Alicja Rafalska-Łasocha

O Marii Skłodowskiej-Curie w 150. rocznicę urodzin

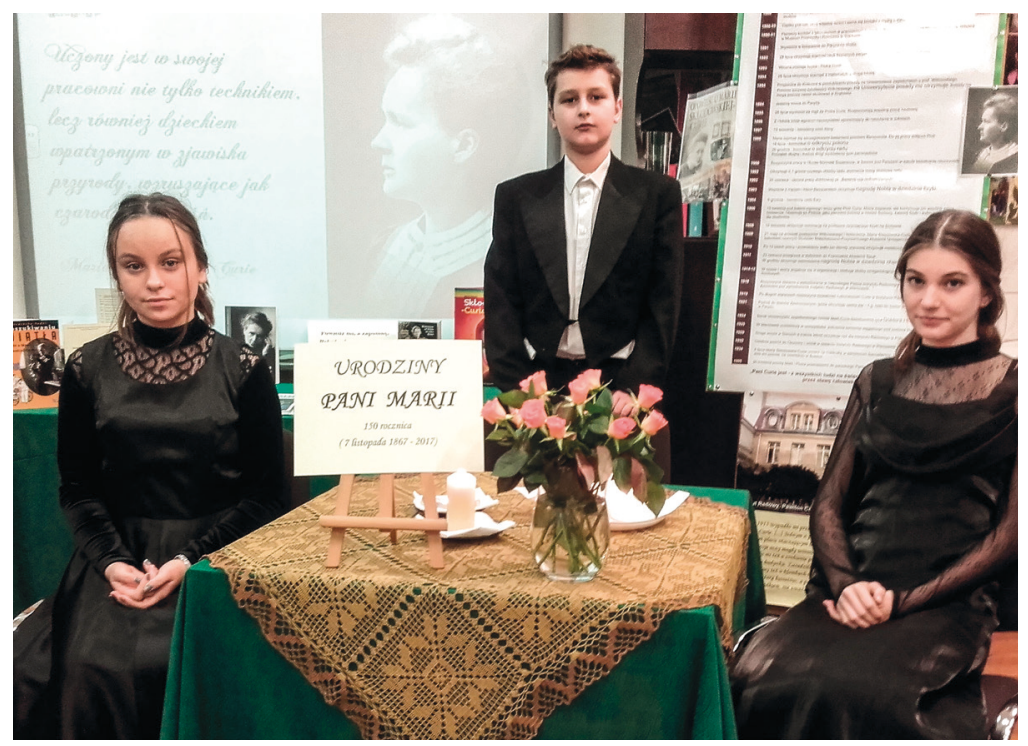

Ryc. 10. Uroczystości urodzinowe Noblistki w Szkole Podstawowej z Oddziałami Integracyjnymi w Jagodnem, woj. świętokrzyskie (fot. Jadwiga Rafalska-Kawalec).

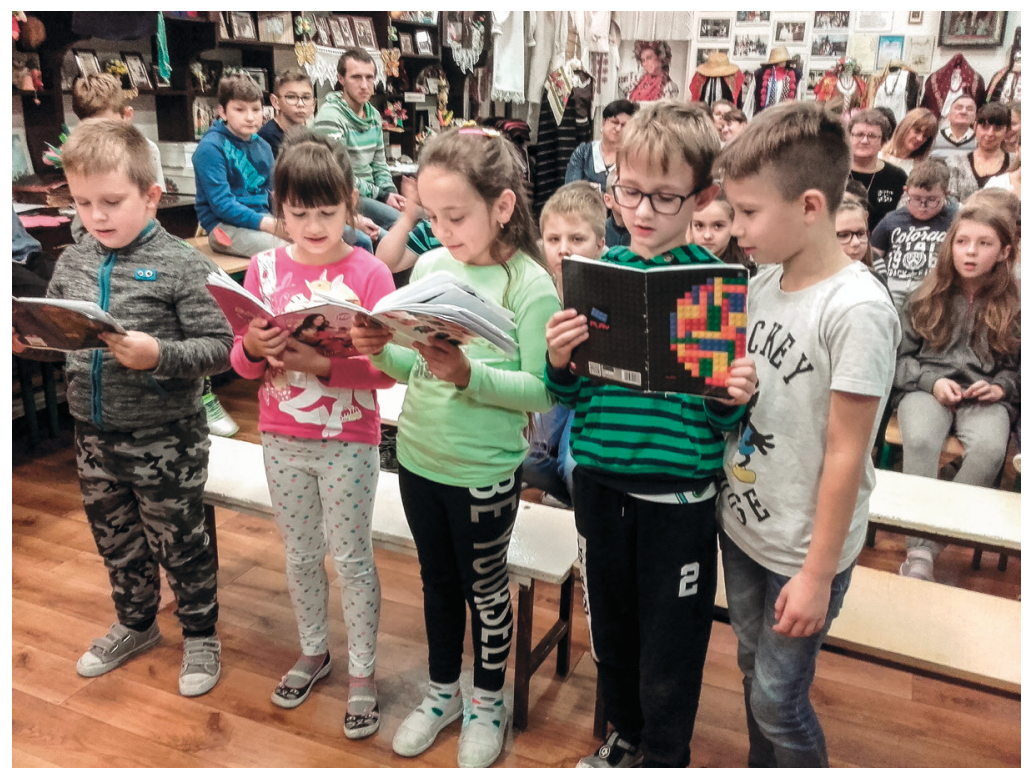

Ryc. 11. Uroczystości urodzinowe Noblistki w Szkole Podstawowej z Oddziałami Integracyjnymi w Jagodnem, woj. Świętokrzyskie (fot. Jadwiga Rafalska-Kawalec). 
przytoczyć wiele placówek edukacyjnych, ale wymieńmy tylko szkołę w Zawieprzycach, miejscowości, którą Maria Skłodowska odwiedzała w młodości, spędzając tam beztroskie wakacje u stryja Ksawerego, gdzie w uroczystościach rocznicowych uczestniczyli goście z Paryża, a wśród nich wnuki uczoneje ${ }^{26}$. Wspomnijmy też niewielką szkołę z oddziałami integracyjnymi w Jagodnem w województwie świętokrzyskim, gdzie również świętowano urodziny Noblistki ${ }^{27}$. Dla uczniów, wśród których są też dzieci niepełnosprawne, zorganizowano święto z Marią Skłodowską w roli głównej i urodzinowymi słodkościami.

\section{Podsumowanie}

Łacińska sentencja mówi: Historia magistra vitae est, ale obecnie historia, w tym również historia nauki, nie jest przedmiotem szczególnego zainteresowania społeczeństwa. Liczba i zasięg wydarzeń związanych z upamiętnieniem i przypomnieniem sylwetki Marii Skłodowskiej-Curie w 150. rocznicę jej urodzin były jednak imponujące. Co więc sprawia, że niektóre postaci historyczne są wciąż ważne i aktualne w świadomości społecznej na całym świecie? Czy przyznana dwukrotnie Nagroda Nobla i odkrycie polonu i radu przez kobietę, w tak ciężkich warunkach, odegrały najważniejszą rolę we współczesnym postrzeganiu tej postaci? W 25-lecie tego odkrycia laureat Nagrody Nobla, francuski fizyk Jean Perrin, rolę Marii i znaczenie jej pracy tak określił:

W tym to właśnie momencie zaznacza się w tej współpracy obojga małżonków osobisty wpływ Marii Curie. Piotra Curie, który przede wszystkim był fizykiem, interesowały same właściwości promieniowania. Niewiele przywiązywał wagi do konieczności wyodrębnienia nowej substancji, do otrzymania jej próbki. To osiagnięcie zawdzięczamy upartej woli pani Curie; bez przesady stwierdzić można, że jest to kamień węgielny, na którym spoczywa gmach promieniotwórczości (Zapiór 1968a).

\footnotetext{
${ }^{26}$ Zob. relację z wydarzeń w Zawieprzycach: Uniwersytet Marii Curie-Skłodowskiej w Lublinie 2017b.

${ }^{27}$ Zob. fotorelację i opis uroczystości: Szkoła Podstawowa z Oddziałami Integracyjnymi w Jagodnem 2017.
} 
O roli badań naukowych w życiu Marii Skłodowskiej-Curie jej biografka Eugénie Cotton pisała:

Dla Marii Curie powołanie naukowe było rodzajem kapłaństwa. Sama znalazła w pracy badawczej zaspokojenie tak żywego u Niej głodu wiedzy i podziwu dla piękna. Była szczególnie wrażliwa na piękno nauki. Nauce otwierającej przed gnanymi żądzą przygody odkrywcami wciąż nowe horyzonty, nauce uzdrawiającej, niosącej ludzkości postęp i łagodzącej ludzkie cierpienia, poświęciła swe życie ${ }^{28}$.

Do powyższych cytatów dodajmy jeszcze słowa samej uczonej:

Mój mąż, a również i ja sama zawsze byliśmy przeciwni czerpaniu jakichkolwiek zysków materialnych z naszego odkrycia. Od samego początku ogłosiliśmy metodę przygotowania radu ze wszystkimi szczegółami. Nie wzięliśmy żadnego patentu i nie zastrzegliśmy sobie żadnych korzyści od producentów. Nie ukryliśmy żadnego najdrobniejszego szczegółu i tylko dzięki ścisłości naszych publikacji przemysł radowy tak szybko się rozwinął. [...] Natomiast wielu przyjaciół nie bez słuszności zwracało nam uwagę, że gdybyśmy zastrzegli swoje prawa, mielibyśmy za co stworzyć doskonały Instytut bez tylu przeszkód, które były wielkim ciężarem dla nas obojga, a dotąd jeszcze są dla mnie. Mimo wszystko sądzę, że postąpiliśmy dobrze.

I jeszcze jeden cytat przywołujący młodość i okres warszawski w życiu Marii. Może właśnie w jej własnych słowach znajdziemy odpowiedź na pytanie, co sprawia, że życie i dzieło Skłodowskiej-Curie są wciąż istotne dla społeczeństwa w XXI wieku. Może jej system wartości i walory etyczne, jak wspomniał Einstein, są ponadczasowe i aktualne również obecnie.

Pozostały mi z owych czasów jasne wspomnienia ze wspólnej pracy umysłowej i społecznej z kolegami. Środki działania były oczywiście znikome, a podobnie i wyniki. Dotąd

${ }^{28}$ Cotton 1965. 
jednak sądzę, że idee, które przyświecały nam wtedy, wskazują na jedyną drogę istotnego postępu społecznego. Niepodobna zbudować lepszego świata bez poprawy losu pojedynczych ludzi; dlatego każdy dążyć winien do poprawy własnej doli, a jednocześnie dzielić odpowiedzialność za całą ludzkość. Jest bowiem szczególnym obowiązkiem pomagać tym, którym możemy być najbardziej użyteczni (Skłodowska-Curie 1959, ss. 20-21).

\section{Bibliografia}

Brian, Denise 2006: Rodzina Curie. Warszawa: Wydawnictwo Amber.

Centrum Dydaktyczne, Warszawski Uniwersytet Medyczny 2017: Program konferencji „Medicina - Scientia - Cultura”. Dostęp online (12.12.2017): http:// msc2017.pl/index.php?id=1.

Cotton, Eugenia 1965: Rodzina Curie i promieniotwórczosć. Warszawa: Wiedza Powszechna.

Curie, Eve 1997: Maria Curie. Warszawa: Państwowe Wydawnictwo Naukowe.

Curie, Maria 1898: Rayons émis par les composés de l'uranium et du thorium. Comptes rendus de l'Académie des Sciences 126, ss. 1101-1103. Publikacja dostępna online (9.12.2017): http:/ / www.academie-sciences.fr/pdf/dossiers/Curie/ Curie pdf/CR1898 p1101.pdf.

Curie, Maria 1921: La radiologie et la guerre. Paris, Librairie Félix Alcan. Publikacja dostępna online (9.12.2017): https://www.irphe.fr/ clanet/otherpaperfile/ articles/PierreCurie/N0067970 PDF 1 168.pdf.

Curie, Piotr; Mme P. Curie,1898: Sur une substance nouvelle radioactive, contenue dans la pechblende. Comptes rendus de l'Académie des Sciences 127, ss. 175-178. Publikacja dostępna online (9.12.2017): http://www.academie-sciences.fr/pdf/ dossiers/Curie/Curie pdf/CR1898 p175 178.pdf.

Curie, Piotr; Mme P. Curie, 1900: Les nouvelles substances radioactives et les rayons qu'elles émettent. Rapports présentés au congrès international de physique, III, ss. $79-114$.

Curie, Piotr; Mme P. Curie, Bémont, Gustave 1898: Sur une nouvelle substance fortement radio-active, contenue dans la pechblende, Comptes rendus de l'Académie des Sciences 127, ss. 1215-1217. Publikacja dostępna online (9.12.2017): $\underline{\text { http:// }}$ www.losavancesdelaquimica.com/wp-content/uploads/1898 NI CR 1215 Curie Radiactividad Pechblenda BR.pdf. 
Ham, Denise 2002-2003: Marie Sklodowska Curie: The Woman Who Opened the Nuclear Age. 21st Century. Science \& Technology Magazine 15(4), Winter 2002-2003, s. 59. Publikacja dostępna online: http://21sci-tech.com/articles/wint02-03/Marie Curie.pdf (9.12.2017).

Institut Curie 2017: Film Pour moi Marie Curie, c'est... You'Tube. Dostęp online (9.12.2017): https://www.youtube.com/watch?time continue $=11 \mathrm{\& v}=\mathrm{ZgQ}-$ AGmm111s.

Joliot-Curie, Irène 2017: Wspomnienie o Marii Skłodowskiej-Curie. Publikacja dostępna online: http://www.ifpan.edu.pl/ON-1/Historia/art/8mar.pdf (9.12.2017).

Kabzińska, Krystyna; Malewicz, Małgorzata; Piskurewicz, Jan; Róziewicz, Jerzy 1994: Korespondencja polska Marii Skłodowskiej-Curie: 1881-1934. Warszawa: Wydawnictwa IHN PAN.

Mould, Richard 2007: Radium History Mosaic. Warszawa: Maria Skłodowska-Curie Memorial Cancer Center and Institute of Oncology.

Muzeum Curie w Paryżu 2017 (9.12.2017): Program imprez organizowanych przez Muzeum Curie w Paryżu. Dostęp online: http://musee.curie.fr/visiter/visiteurs-individuels/presentation.

Muzeum Marii Skłodowskiej-Curie w Warszawie 2017: Program wydarzeń organizowanych przez Muzeum Marii Skłodowskiej-Curie w Warszawie. Dostęp online (9.12.2017): http://www.muzeum-msc.pl/historia-muzeum/obchody-rocznicy/146-jubileuszowe-logo-obchodow-150-rocznicy-urodzin-marii-sklodowskiej-curie.

Rafalska-Lasocha, Alicja 2015: Maria Sktodowska-Curie i jej kontakty ze środowiskiem krakowskim. Kraków: Polska Akademia Umiejętności, ISBN 978-83-7676-2210. Publikacja dostępna online (9.12.2017): http://pau.krakow.pl/index.php/ $\mathrm{pl} /$ wydawnictwo/publikacje-on-line/inne/alicja-rafalska-lasocha-maria-sklodowska-curie.

Rafalska-Łasocha, Alicja 2017: Maria Skłodowska-Curie i kwiaty. Wiadomości Uniwersyteckie, październik 2017, ss. 39-42. Publikacja dostępna online (9.12.2017): http://serwisy.umcs.lublin.pl/wiadomosci/wu 237 net.pdf.

Mme Skłodowska-Curie, Marie 1903: Doctoral thesis by Marie Sklodowska-Curie, 1903. Publikacja dostępna online (9.12.2017): https://commons.wikimedia.org/ wiki/File:Doctoral thesis by Marie Curie (1903).pdf

Skłodowska-Curie, Marie 1959: Autobiografia. Warszawa: Państwowe Wydawnictwo Naukowe.

Szkoła Podstawowa z Oddziałami Integracyjnymi w Jagodnem 2017: Urodziny Pani Marii w Szkole Podstawowej z Oddziałami Integracyjnymi w Jagodnem. Dostęp online (12.12.2017): http://www.spjagodne.szkolnastrona.pl/index. php? $\mathrm{p}=$ new \&idg $=\mathrm{mg}, 28 \& \mathrm{did}=226 \&$ action $=$ show. 
Uniwersytet Marii Curie-Skłodowskiej w Lublinie 2017a: Program imprez organizowanych przez Uniwersytet Marii Curie-Skłodowskiej w Lublinie. Dostęp online (12.12.2017): http://www.umcs.pl/pl/urodzinymarii.htm.

Uniwersytet Marii Curie-Skłodowskiej w Lublinie 2017b: 150. Rocznica Urodzin Marii Curie-Skłodowskiej (1867-2017). Galeria zdjęć. Listopad 2017. Delegacja z Paryża w Zawieprzycach. Dostęp online (12.12.2017): http://www. umcs.pl/pl/galeria-150-rocznica-urodzin-marii-curie-sklodowskiej-umcs-lublin,11942,delegacja-z-paryza-w-zawieprzycach, 57387.chtm.

Uniwersytet Marii Curie-Skłodowskiej w Lublinie 2017c: 150. Rocznica Marii Curie-Skłodowskiej 1876-2017. Wiadomości Uniwersyteckie nr 8/237. Dostęp online (12.12.2017): http://serwisy.umcs.lublin.pl/wiadomosci/wu_237_net.pdf.

Wydział Chemii UJ 2017: „Maria Skłodowska-Curie i kwiaty”. Wystawa zorganizowana przez Wydział Chemii UJ. Dostęp online (12.12.2017): http://www. biurokarier.chemia.uj.edu.pl/wystawy/maria-sklodowska-curie-i-kwiaty.

Zapiór, Bronisław 1969: Wpływ dzieła Marii Skłodowskiej-Curie na rozwój nauk chemicznych. Odczyt wygłoszony w Auli UJ w dniu 12 grudnia 1967 roku z okazji obchodu 100 rocznicy urodzin Marii Skłodowskiej. Zeszyty Naukowe Uniwersytetu Jagiellońskiego. Prace Chemiczne 14, ss. 9-29.

Zapiór, Bronisław 1969: Działalność Marii Skłodowskie-Curie a rozuój chemii. Kraków: Państwowe Wydawnictwo Naukowe Oddział w Krakowie. 